\title{
Subjectship, Citizenship, and the Long History of Immigration Regulation
}

\author{
ROBERT J. STEINFELD
}

Kunal Parker's "State, Citizenship, and Territory" can be read in at least two ways. Read one way, it tells an important story about how regulation of the poor was driven upward in Massachusetts during the nineteenth century, from the localities to the state. In the seventeenth century, Massachusetts had imposed primary responsibility for care of the poor on its towns. But during the eighteenth century, with the growth of a landless, wandering population, town poor relief budgets came under increasing pressure. The towns responded by lobbying the Massachusetts legislature to pass a series of statutes that made it more and more difficult to acquire a town settlement. People who fell into need in Massachusetts but who had not acquired a town settlement became state paupers for whom the state, rather than any town, was fiscally responsible. As it became more and more difficult to acquire a town settlement, the number of state paupers increased, shifting a portion of the fiscal burden of poor relief from the towns onto the state.

From the state's perspective the poor relief system created perverse incentives for the towns. Because the towns actually administered the poor relief system for both town paupers and state paupers, they had every inducement to exaggerate the number of state paupers, for whose expenses they were reimbursed, and to understate the number of town paupers, for whom they remained fiscally responsible. This system also gave towns little incentive to remove state paupers to the places where they might have a settlement, and where they would once again become town paupers since towns were completely reimbursed for the state pauper expenses they bore.

As overseas immigration picked up in the 1820 s and 1830 s, the number of state paupers grew, placing greater fiscal pressures on the state, which the conduct of the towns only served to exacerbate. Gradually, the state was forced into assuming greater and greater oversight of the towns and began

Robert J. Steinfeld is Professor of Law at the State University of New York at Buffalo. 
to take over and directly administer some of the functions for which the towns had previously been responsible. State regulation grew as the state wrested administrative authority away from the localities. But the motivation for this transfer of authority was not a desire to expand state power; it was a desire to avoid fiscal imposition by the towns. A more powerful state was, in a sense, the unintended consequence of these acts of fiscal self-defense.

Versions of this story have been told before but in the majority of earlier accounts, the state's expanded role in poor relief has simply been ascribed to the growth of an unsettled population. Parker's account adds a crucial political dimension to this heretofore almost entirely demographic story. Read this way, the article contributes important insights into the processes that drove regulation of the poor upward from the towns to the state in the nineteenth century.

Read a second way, however, the article seeks to tell a more ambitious story of the development of American citizenship as a gesture of refusal or exclusion rather than as the unfolding of national identity. Essentially, Parker's argument is that the same processes that led Massachusetts to defend itself against fiscal imposition by the towns also led it to begin to defend itself against the demands of immigrants. The great wave of immigration into Massachusetts from the 1820 s to the 1850 s led to a huge increase in the number of state paupers, and of these a growing proportion were immigrants.

The Commonwealth reacted by beginning to use citizenship as a device for limiting the claims of immigrants to enter and remain on Massachusetts territory and to seek support from the community when they fell into need. Massachusetts began to limit entry to its territory by enacting the Passenger Acts. It limited the rights of immigrants to remain on its territory by invoking various provisions in its Poor Law. Immigrants who sought poor relief could be sent back to their points of origin. These acts of refusal were accompanied by the development of a state discourse that sought to portray immigrants as alien other in order to justify restrictions on their territorial and welfare claims.

Parker argues that this was a new development. By contrast, during the eighteenth and early nineteenth centuries, before Massachusetts had to contend with a large immigrant population, the right to enter and remain on Massachusetts territory had not been tied to citizenship but to town settlement, had not been controlled by the state but by the localities. The territorialization of the boundaries of Massachusetts was new, as was the linkage of both territorial rights and rights of support to citizenship. And these developments could be traced to the success the towns had earlier had in shifting responsibility for poor relief onto the state and to the fiscal difficulties this shift created for the state when it began to have to deal with the effects of a large wave of immigration. 
This argument seems completely plausible, knowing what we do of the ugly nativism that developed in Massachusetts during this period. But there is other evidence that Parker does not discuss which suggests that his argument may exaggerate the novelty of the steps Massachusetts took in the 1830 s and 1840 s to deal with immigrants and the novelty of the state discourse used to justify these steps.

Massachusetts had long been concerned with the quality and character of arriving immigrants. In the eighteenth century, the colony passed a series of laws to address these problems. And Massachusetts was not alone. Other colonies also passed laws to deal with problems that dissolute, infirm, and aged immigrants might create and to limit the entry of certain groups of aliens who were considered particularly undesirable. A number of these colonial laws created bonding and fee schemes that were strikingly similar to the ones in the Passenger Acts. The Passenger Acts seem to have represented the culmination of an older tradition of immigration regulation rather than the beginning of a new one. They appear to look backward rather than forward to the harsher, more comprehensive schemes that began to be established with the passage of the Chinese Exclusion Act in 1882.

This evidence also suggests different motives for the late eighteenthcentury Massachusetts law that Parker discusses in his article. It indicates that by the end of the eighteenth century there was a well-established tradition of using citizenship (subjectship) as refusal and that this older tradition found expression in the settlement act of 1794 and in the Massachusetts alien real property disability.

In a number of colonies and later states, statutes were enacted during the eighteenth century that put into place immigration regulations similar to the ones later adopted in the Passenger Acts.

In Massachusetts, statutes were passed, beginning in 1701, to prevent the landing of the "poor, vicious and infirm," laws that required the master of each vessel to post a bond that towns receiving any "lame, impotent, or infirm persons, incapable of maintaining themselves ... would not be charged with their support." In the absence of this security, the captain was to return such passengers to their port of embarkation. ${ }^{1}$

This provision was renewed in 1723,1725 , and 1757 . Other colonies sought to restrict the entry of Catholics, Irish, Germans, and other aliens. In Pennsylvania, the immigration of a large number of Germans in 1727 created fears that these "strangers" who were "ignorant of our Language \& Laws" sity Press, 1998), 71-72. 
would create grave problems for the Commonwealth. In 1729, as a result, Pennsylvania enacted a law that

levied a duty of forty shillings on "every person being an alien born out of the allegiance of the King of Great Britain ... coming into this province by land or water" and twenty shillings on "any Irish servant or passenger upon redemption."

In Maryland in the early eighteenth century the legislature passed an act that

required the masters of vessels "or others importing Irish Servants into this Province by Land or by Water" to pay twenty shillings sterling "per poll." The purpose of this law, according to the act's title, was to raise "a Supply to defray the Public Charge ... and ... to prevent the Importing too great a number of Irish Papists into this Province." Similar steps were taken by Virginia's legislature ... [w]hen in 1699 the burgesses laid a duty of fifteen shillings on "every servant not born in England or Wales. ..."3

After the Revolution,

Americans retained their colonial reluctance to serve as a regenerative haven for Europe's failures - men who would enervate rather than strengthen the new nation... . Postwar governments did their best to staunch the influx of infirm and dissolute immigrants. In 1788 Massachusetts reenacted colonial laws requiring the registration of foreigners and prohibiting the landing of aliens who were likely to need public relief. ${ }^{4}$

From the beginning, Americans had a double-sided view of immigrants and immigration. On the one hand, they frequently saw immigrants as a critical source of future prosperity. On the other, they were concerned that only the right sort of immigrants should come into the country. After the Revolution, Massachusetts seems to have had a more restrictive immigration policy than some other states. Indeed, one Massachusetts man complained that this restrictive policy would result in the state falling economically behind other regions of the country. When, after the Revolution, a number of states abolished the alien real property disability in order to encourage immigration, Massachusetts did not..$^{5}$ Indeed, Parker quotes from a 1785 Massachusetts bill that sought to reaffirm in the strongest terms the alien real property disability in the state.

After the Revolution and through the 1790s the new nation engaged in a sweeping debate about alienage and the terms of naturalization. The Naturalization Act of 1795 and the Alien, Sedition and Naturalization Acts

2. Ibid., 72-73.

3. Ibid., 84.

4. Ibid., 197.

5. Ibid., 212 (economic effects), 218 (alien real property disability). 
of 1798 were expressions of how deeply these issues exercised Americans during this period.

Although most of the delegates to the Constitutional convention wished to avoid giving "the tincture of illiberality to the Constitution," none of them could completely shake the belief that foreigners "bring with them, not only attachments to other countries, but ideas of government so distinct from ours, that in every point of view they are dangerous." ${ }^{6}$

"In 1795 Federalists and Republicans agreed that foreigners needed a longer period of acculturation and closer scrutiny before entering America's political arena." A nephew of President John Adams wrote that "the grand cause of all our present difficulties may be traced ... to so many hordes of Foreigners imigrating [sic] to America. ..."8 But after 1795 the Republican and the Federalist Parties went separate ways and the Federalists began to embrace an even more robust nativism. In Massachusetts, the legislature was dominated and controlled by Federalists.

Even after Jefferson was elected president in 1800, the Naturalization Act of 1802 continued to include many provisions found in the 1795 and 1798 Federalist naturalization acts.

Any immigrant arriving after the passage of the Act of 1802 was now required to present a certificate issued by a court clerk declaring that he had registered as an alien prior to petitioning for naturalization. This "alien report" recorded a foreigner's name, birthplace, age, allegiance, country of origin, and intended place of settlement. ... The registration of immigrants and resident aliens was a dramatic expansion of the power of government to intrude into the lives of America's immigrants. ${ }^{9}$

There are three things that should be said about the Massachusetts Passenger Acts of the 1830s and 1840s and the discourse that was deployed to justify them. First, in their concern for the fiscal burdens that immigrants might impose on the Commonwealth and in the mechanisms they established to try to address this problem, they seem to have been completely traditional, harking back to schemes that had been used in various colonies since the eighteenth century.

Second, the state discourse about the alien, corrupt character of foreigners that was used to justify the treatment of aliens during the 1830 s and 1840 s does not seem to have been substantially different from discourses that had been used intermittently for over a century in connection with efforts to limit the immigration of Irish Papists, Germans, Jews, or postFrench Revolutionary radicals. The precise character of the concerns ex-

6. Ibid., 234.

7. Ibid., 267.

8. Quoted in ibid., 270. Emphasis in original.

9. Ibid., 309. 
pressed about foreigners in the nineteenth century may have been somewhat different than the character of the concerns expressed in the eighteenth century, but over this period there was remarkable continuity in the impulse to portray the alien foreigner as other and to try to limit the immigration of certain groups on that ground.

Third, the Passenger Acts do not seem to have been direct precursors of the harsher form of immigration regulation that began to be put into place during the last quarter of the nineteenth century. They did not refuse immigrants entry into Massachusetts territory outright but conditioned entry upon the payment of a significant, but not prohibitive, $\$ 2$ fee in many cases, or upon the posting of a $\$ 1000$ bond in the case of the aged and infirm. This was a weak form of territorialization and a far cry from the modern regime of immigration, which took its final form during the 1920s. That regime flatly excluded (excludes) most immigrants from the country unless they could (can) specially qualify under the law.

Parker acknowledges that the Passenger Acts did not actually refuse immigrants entry into Massachusetts and represented only a weak form of territorialization but goes on to point out that Massachusetts did refuse immigrants rights to remain on its territory under Poor Law. And this is unquestionably true. Immigrants without a settlement in a Massachusetts town could be removed from the Commonwealth and sent overseas should they seek poor relief. But this gesture of refusal of territorial rights applied equally to immigrants and citizens. Any citizen who had not managed to establish a settlement in a Massachusetts town could also be removed to the place that was responsible for his support. Parker devotes several pages to describing how Massachusetts officials could, at times, work hard to return citizen paupers to the states from which they had come and which remained responsible for their support. One Massachusetts official, Parker writes,

assiduously visited neighboring states to investigate whether the responsibility for some state paupers might not be pinned onto governmental bodies there. In 1855, "to facilitate the discovery of [town] settlements of persons claiming support from the State, [this official] journeyed into Maine, New Hampshire, Vermont, Rhode Island and Connecticut, and . . . found a home for one hundred and five [state] paupers." 10

Citizens who had not managed to acquire a town settlement also stood upon exactly the same footing as aliens when it came to claims upon the community for support. Both were entitled to receive interim poor relief as Massachusetts state paupers so long as the state did not opt to remove

10. Kunal Parker, "State, Citizenship, and Territory: The Legal Construction of Immigrants in Antebellum Massachusetts," Law and History Review 19 (2001): 634. 
them to their places of origin. Indeed, even Massachusetts citizens could be removed to their towns of origin.

Parker recognizes that the similarities in the treatment of citizen paupers without settlements and alien paupers create some difficulties for his argument. His response is to urge that citizenship should be understood as a gesture of pure refusal, one that did not entail any notion that citizenship brought any particular advantages. But I find this argument difficult to accept. If we say that citizenship is a gesture of refusal, it must be to establish that in some respects at least citizenship gives something that alienage does not. If citizenship gives no more than alienage, it is not alienage against which the gesture of refusal operates but some other characteristic that citizen and alien share. In this case, the main gesture of refusal seems to have been one aimed at poor people without settlements in Massachusetts towns, regardless of whether they were citizens or aliens. In the end, the case seems weak for seeing this particular refusal of territorial rights under Poor Law as one based on citizenship.

Ironically, there are clear gestures of citizenship as refusal to be found in Massachusetts Poor Law, and in Massachusetts law generally, but they appear decades before the 1830s and 1840s. The 1794 Massachusetts Settlement Act, and the alien real property disability, which continued in effect in Massachusetts long after the Revolution, excluded aliens from important legal entitlements purely on the ground that they were not citizens. But Parker sees these earlier gestures not as gestures of citizenship as refusal but as more traditional gestures somehow not based on citizenship.

The 1794 Massachusetts settlement act, for example, explicitly prohibited aliens from acquiring a town settlement by demonstrating that they were capable of supporting themselves. Parker argues that the statute was written as it was only because the towns feared that aliens, who could not own real property in Massachusetts, would pose a greater fiscal risk for towns than American citizens. The act of refusal contained in the statute was not anti-alien. It was simply anti a group of people who could not own real property and hence who could not achieve the economic self-sufficiency and political independence that ownership of real property was then thought to bring.

Parker has not found direct evidence for this reading of the statute, and in light of what we know about an older tradition of using citizenship/subjectship as a gesture of refusal and of the Massachusetts legislature's strong Federalist, anti-immigrant posture during this period, a better reading of the statute, I think, would cast it as a clear gesture of citizenship as refusal.

The 1794 statute continued to make the common law modes of acquiring a settlement available to aliens: marriage, serving an apprenticeship, serving as a town officer or minister, and so forth. But, as Parker rightly 
points out, these were modes of acquiring a settlement that were not meant for the complete outsider. Complete outsiders could acquire a town settlement under the statute by demonstrating a capacity to support themselves over a period of time-but only if they were American citizens. American citizens could acquire a town settlement in Massachusetts by demonstrating economic capacity in one of three ways: (1) through ownership of real property of a certain value for three years running, or (2) through ownership of an estate (personal property or mixed personal and real property) of a certain value for five years running, or simply (3) through residence for ten years together with tax paying for five years. Only the first method required ownership of real property.

An American citizen could gain a town settlement under this statute without ever having owned real property. It is true that aliens were legally precluded from owning real property in Massachusetts, but they were not legally precluded from owning personal property or from paying taxes. They were in a legal position to demonstrate economic capacity under two of the three methods set out in the statute, but the statute expressly disqualified noncitizens from doing so.

On its face the statute treated noncitizens differently from citizens and it strikes me that a less labored reading of the statute would be that it flatly precluded noncitizens from becoming members of Massachusetts town communities even if they could demonstrate economic capacity, a clear example of citizenship as refusal. This reading is strongly supported by what we know about the debates over alienage and naturalization that were taking place in the 1790s and about the posture of the Massachusetts legislature toward aliens during this period.

Parker's reading of the 1794 statute, moreover, depends upon the fact that aliens were prohibited from owning real property in Massachusetts. But that raises the question why aliens were prohibited from owning real property in the state in the first place? Why was this disability itself not evidence of citizenship as a gesture of refusal? Parker seems to see the real property disability as a matter of pure tradition going back to English law, a tradition that had merely lingered on in Massachusetts. But the evidence suggests that the alien real property disability became a live issue after the Revolution. A number of states repealed the disability, hoping to encourage immigration; Massachusetts did not. This was no mere lingering on of tradition, it was conscious post-Revolutionary Massachusetts policy aimed at protecting the Commonwealth from the undue influence of aliens.

The difficulty with the main argument of this article, it seems to me, is that where it looks for citizenship as refusal in the middle decades of the nineteenth century, the explicit gestures of refusal it finds are not substantially different from gestures of refusal that Massachusetts and other colo- 
nies had engaged in, on and off, for more than a century and that they had long justified on the ground that aliens (at least some aliens) were other. The Massachusetts policy of these decades seems to have represented the culmination of an older tradition of using citizenship/subjectship as refusal rather than the beginning of a new one. And at times this older tradition had produced even harsher gestures of refusal than those that were to be found in the middle decades of the nineteenth century. I take the Massachusetts real property disability and the settlement act of 1794 to represent examples of this older tradition at its worst. Not until the last quarter of the nineteenth century did the regulation of immigration begin to take on a new, even harsher, more comprehensive form, one that would lead in the twentieth century to the thoroughgoing territorialization of the nation.

Parker's real contribution is to lay bare some of the pressures that were responsible during the first decades of the nineteenth century for driving regulation of the poor upward, for leading the state to take away from the localities the administration of certain important aspects of poor relief and immigration policy. By contrast, the substantive policies that the state began to administer during this period do not seem to have represented a marked departure from policies that had been utilized, intermittently, to manage immigration for over a century. 